\title{
Cropping system diversification for food production in Mindanao rubber plantations: A rice cultivar mixture and rice intercropped with mungbean
} Rosa Fe Hondrade ${ }^{1}$, Edwin Hondrade ${ }^{1}$, Lianqing Zheng ${ }^{2,3}$, Francisco Elazegui ${ }^{4}$ ， Jo-Anne Lynne Joy E Duque , Christopher C Mundt ${ }^{6}$, Casiana M Vera Cruz ${ }^{7}$, Karen A Garrett ${ }^{\text {Corresp. } 2,8,9,10}$

1 University of Southern Mindanao, Cotabato, Philippines

2 Department of Plant Pathology, Kansas State University, Manhattan, Kansas, United States

3 Department of Statistics, Kansas State University, Manhattan, Kansas, United States

4 International Rice Research Institute, Los Banos, Philippines

5 University of Southern Mindanao, Kabacan, North Cotabato, Philippines

6 Plant Pathology Department, Oregon State University, Corvallis, Oregon, United States

7 Genetics and Biotechnology Division, International Rice Research Institute, Los Banos, Philippines

8 Institute for Sustainable Food Systems, University of Florida, Gainesville, United States

9 Plant Pathology Department, University of Florida, Gainesville, United States

10 Emerging Pathogens Institute, University of Florida, Gainesville, United States

Corresponding Author: Karen A Garrett

Email address: karengarrett@ufl.edu

Including food production in non-food systems, such as rubber plantations and biofuel or bioenergy crops, may contribute to household food security. We evaluated the potential for planting rice, mungbean, rice cultivar mixtures, and rice intercropped with mungbean in young rubber plantations in experiments in the Arakan Valley of Mindanao in the Philippines. Rice mixtures consisted of two- or three-row strips of cultivar Dinorado, a cultivar with higher value but lower yield, and high-yielding cultivar UPL Ri-5. Rice and mungbean intercropping treatments consisted of different combinations of two- or threerow strips of rice and mungbean. We used generalized linear mixed models to evaluate the yield of each crop alone and in the mixture or intercropping treatments. We also evaluated a land equivalent ratio for yield, along with weed biomass (where Ageratum conyzoides was particularly abundant), the severity of disease caused by Magnaporthe oryzae and Cochliobolus miyabeanus, and rice bug (Leptocorisa acuta) abundance. We analyzed the yield ranking of each cropping system across site-year combinations to determine mean relative performance and yield stability. When weighted by their relative economic value, UPL Ri-5 had the highest mean performance, but with decreasing performance in lowyielding environments. A rice and mungbean intercropping system had the second highest performance, tied with high-value Dinorado but without decreasing performance in lowyielding environments. Rice and mungbean intercropped with rubber have been adopted by farmers in the Arakan Valley. 


\section{Cropping system diversification for food production in Mindanao rubber}

\section{2 plantations: A rice cultivar mixture and rice intercropped with mungbean}

3

4 Short title: Plantation diversification for food

5

6 R. F. Hondrade ${ }^{*}$, E. Hondrade ${ }^{*}$, L. Zheng ${ }^{23^{*}}$, F. A. Elazegui ${ }^{4}$, J. L. E. Duque ${ }^{1}$, C. C. Mundt ${ }^{5}$, C.

7 M. Vera Cruz ${ }^{4}$, K. A. Garrett ${ }^{2678}$

8

$9 \quad{ }^{1}$ University of Southern Mindanao, Cotabato, Philippines

10 2Department of Plant Pathology, Kansas State University, Manhattan, KS, United States

$11{ }^{3}$ Department of Statistics, Kansas State University, Manhattan, KS, United States

$12{ }^{4}$ International Rice Research Institute, DAPO Box 7777, Metro Manila, Philippines

$13{ }^{5}$ Department of Botany and Plant Pathology, Oregon State University, Corvallis, United States

$14{ }^{6}$ Institute for Sustainable Food Systems, University of Florida, Gainesville, FL, United States

15 7Plant Pathology Department, University of Florida, Gainesville, FL, United States

$16{ }^{8}$ Emerging Pathogens Institute, University of Florida, Gainesville, FL, United States

17 Current address of L. Zheng: Gilead Sciences, Inc., Foster City, CA, United States

$18 *$ These authors contributed equally to this work

19 Corresponding author: K. A. Garrett, karengarrett@ufl.edu 


\section{ABSTRACT}

22 Including food production in non-food systems, such as rubber plantations and biofuel or

23 bioenergy crops, may contribute to household food security. We evaluated the potential for

24 planting rice, mungbean, rice cultivar mixtures, and rice intercropped with mungbean in young

25 rubber plantations in experiments in the Arakan Valley of Mindanao in the Philippines. Rice

26 mixtures consisted of two- or three-row strips of cultivar Dinorado, a cultivar with higher value

27 but lower yield, and high-yielding cultivar UPL Ri-5. Rice and mungbean intercropping

28 treatments consisted of different combinations of two- or three-row strips of rice and mungbean.

29 We used generalized linear mixed models to evaluate the yield of each crop alone and in the

30 mixture or intercropping treatments. We also evaluated a land equivalent ratio for yield, along

31 with weed biomass (where Ageratum conyzoides was particularly abundant), the severity of

32 disease caused by Magnaporthe oryzae and Cochliobolus miyabeanus, and rice bug (Leptocorisa

33 acuta) abundance. We analyzed the yield ranking of each cropping system across site-year

34 combinations to determine mean relative performance and yield stability. When weighted by

35 their relative economic value, UPL Ri-5 had the highest mean performance, but with decreasing

36 performance in low-yielding environments. A rice and mungbean intercropping system had the

37 second highest performance, tied with high-value Dinorado but without decreasing performance

38 in low-yielding environments. Rice and mungbean intercropped with rubber have been adopted

39 by farmers in the Arakan Valley.

40 


\section{INTRODUCTION}

43 The spread of agricultural non-food systems, such as rubber plantations, is a major factor for

44 smallholder farmers and farm laborers, who often must navigate potential shifts from traditional

45 swidden systems (Fox \& Castella 2013; Josol \& Montefrio 2013; Li et al. 2014; Manivong \&

46 Cramb 2008; Mertz et al. 2013; Montefrio \& Sonnenfeld 2013; van Vliet et al. 2012;

47 Vongvisouk et al. 2014). Increasing rubber production has the potential to reduce household

48 food security, if less land is used for local food production (Weinberger 2013). In addition, the

49 cleared land between young trees is wasted from an economic standpoint, and may be subject to

50 erosion, if it is not planted with other crops. The use of intercropping of food crops in tree

51 plantations has the potential to address both of these problems. Rubber trees may be

52 intercropped with a range of other plant species, including food crops and tea, cocoa, coffee,

53 rattan, fruit trees, and cinnamon (Jessy et al. 2016; Pathiratna \& Perera 2006; Penot \& Ollivier

54 2009; Wu et al. 2016). Guo et al. (2006) concluded that rubber-tea intercropping provided an

55 economic benefit compared to separate rubber and tea monocultures in Hainan, China. Rubber

56 intercropping with a crop like banana, before latex is produced, may even ultimately improve

57 rubber production (Rodrigo et al. 2005). Systems of rubber intercropping in Nigeria often gave

58 improved productivity, including systems of intercropping with soybean and melon, or with

59 melon and maize (Esekhade et al. 2003). In Kerala, India, adoption of intercropping of rubber

60 with pineapple, banana, and cassava was reported as most common (Rajasekharan \&

61 Veeraputhran 2002).

62 Planned diversification of plantations can be implemented at multiple scales.

63 Smallholder farms have included both small-scale rubber production and rice (Dove 1993). An

64 annual cropping system intercropped in rubber plantations might include intercropping of a 
65 staple cereal with a legume for additional nutritional benefits to local consumers. Including a

66 legume in the system can also increase $\mathrm{N}$ availability in soils (Schroth et al. 2001; van

67 Noordwijk et al. 2004). Within the cereal species, the use of cultivar mixtures may provide

68 additional benefits (Finckh et al. 2000; Garrett \& Mundt 1999; Meung et al. 2003). A striking

69 example is the great success of rice mixtures composed of a rice cultivar with higher economic

70 value but susceptible to rice blast, with a rice cultivar with lower economic value but resistant to

71 rice blast (Zhu et al. 2000). Diversification to include plants that support the natural enemies of

72 crop pests (Gurr et al. 2016) or that repel pests or attract them away from crops (Khan et al.

73 2000) may also provide benefits to production. The effects of increased system diversity can be

74 difficult to predict, however, and functional diversity designed to achieve particular cropping

75 system goals may be more useful than haphazardly constructed diversification. The effects of

76 system diversification need to be studied in field experiments because what seem like intuitive

77 outcomes may not be observed in practice.

78 In the Arakan Valley of Mindanao, the southernmost island group of the Philippines,

79 demand for rubber drove replanting because the majority of rubber trees in the region were more

80 than 30 years old and had reduced latex production (R. Hondrade, personal observation). When

81 replanting, farmers would need to wait approximately five to seven years before they could begin

82 tapping the new rubber trees. This interval is an opportunity for the production of annual crops

83 such as upland rice, corn, vegetables, and grain legumes between the immature rubber trees,

84 before the rubber trees are large enough that interspecific competition becomes an important

85 factor. Such intercropping can produce household food and may also generate income while

86 waiting for the rubber trees to reach a productive age. 
88 in rubber agroforestry that included mungbean (Vigna radiata) intercropped with rice mixtures.

89 We evaluated the effects of (1) rubber tree age, (2) rice cultivar and the combination of cultivars,

90 and (3) rice and mungbean intercropping, on crop yield and the level of biotic constraints -

91 disease severity, insect abundance, and weed biomass. We also illustrate the use of a split plot

92 design in generalized linear mixed models for intercropping that could be useful for analysis of

93 other intercropping experiments, and an analysis of the yield ranking of each cropping system

94 across site-year combinations to evaluate mean relative performance and yield stability.

95

96 MATERIALS AND METHODS

\section{Experimental sites}

98 The experimental sites were in the Arakan Valley Complex in the province of Cotabato in

99 Central Mindanao, Philippines. Arakan has 28 villages, 10 of which are major rice producing

100 villages. Its total land area is 69,432.79 ha with about 16,798 ha utilized for crop production.

101 The landscape of Arakan is dominated by rolling hills, valleys, and mountain ranges.

\section{Planting design}

103 We evaluated the set of eight cropping treatments (Table 1), described in more detail below, in

104 farmers' fields for three seasons (2006-2008), with planting date details in Table S1. In 2006,

105 two fields, one with 1-year-old rubber trees and one with 3-year-old rubber trees, were selected

106 in each of three municipalities - Antipas, Arakan, and Pres. Roxas - to represent local systems.

107 The experimental design in 2006 was a split-plot design with rubber tree age as the whole plot

108 treatment (Figure S1a). Each farm contained three complete blocks, with each block containing 
$10910 \mathrm{~m} \mathrm{x} 4 \mathrm{~m}$ subplots that were assigned to the eight intercropping treatments (Table 1; Figs. 1

110 and S1b).

111 Due to water-logging in some municipalities, the experiments in 2007-2008 were moved.

112 During these years, two-year experiments were conducted in three fields with 1- to 2-year-old

113 rubber trees in the municipality of Arakan, in the villages of Doroluman, Naje, and Sabang. The

114 experiment was established in 2007 on 17 July (Doroluman, with 1-year-old rubber), 12 June

115 (Sabang with 1.5-year-old rubber), and 16 May (Naje with 2-year-old rubber) (Table S1). The

116 experimental design in 2007-2008 was a split-plot design with the two years as repeated

117 measures (Fig. S2). The whole plots were again individual farms, with farm effects considered a

118 random effect. Each farm again contained three complete blocks, with the eight intercropping

119 treatments (Table 1) applied to the subplots.

120 Eight rice and mungbean treatment combinations (Table 1) were planted in plots between

121 the rubber tree rows. Two rice cultivars were included in the design: Dinorado, a higher-value

122 but lower-yielding cultivar, and UPL Ri-5, a higher-yielding but lower-value cultivar, along with

123 a high-yielding mungbean variety, Pag-asa 7. Subplots were positioned between the rows of

124 rubber trees. Each subplot was $10 \mathrm{~m}$ long and included 10 rows of rice and/or mungbean, with

$1250.4 \mathrm{~m}$ between rows and $0.2 \mathrm{~m}$ between hills for both rice and mungbean. The distance between

126 the subplots and the base of the rubber trees was 1-1.5 m, and there was a $4 \mathrm{~m}$ border between

127 the experimental plots to reduce interplot interference. In general pesticides were not used, with

128 the exception of the Oreta one-year-old rubber farm in 2006. Hand weeding was implemented

129 following standard farmer practices to support establishment of the crops.

\section{Statistical analysis}


131 The response variables evaluated were crop yield, land equivalent ratio, weed biomass, crop

132 height, and the disease and pest ratings for each crop. The responses represent a range of

133 different probability distributions for statistical analyses. Several response variables were

134 approximately normally distributed, so these data were analyzed in a linear mixed model using

135 the MIXED procedure in SAS (Version 9.2). The details of the ANOVAs are given in Tables S2

136 and S3, following the design structures in Figures S1 and S2.

137 The same model structure was used for generalized linear mixed models for response

138 variables that were not normally distributed, such as some disease ratings. The assumption of

139 normality was tested using a Shapiro-Wilk test, and a Q-Q plot was evaluated where a heavy tail

140 suggested use of a gamma distribution. Because of an upward skew in some data, the gamma

141 distribution with $\log$ link function was used to analyze those responses using SAS Proc

142 GLIMMIX. The ilink option was used for calculating the least square means. A Tukey-Kramer

143 adjustment (at significance level 0.05) was used in multiple comparisons of performance within a

144 crop across the different treatments in which that crop occurred. Weed dry weight was evaluated

145 for each treatment (not evaluated separately for different crops). Weed weight was

146 approximately normally distributed after square root transformation. We evaluated the effects of

147 rubber tree age and cropping treatments (including the no-crop treatment) on weed weight in a

148 linear mixed model. Ratings of disease severity were treated in analyses as approximately

149 continuous.

\section{Yield and economic value of intercrops: rice and mungbean}

151 Both UPL Ri-5 and Dinorado are preferred rice varieties of Arakan farmers for various reasons

152 (R. F. Hondrade, personal observation). Both mature in approximately 128 days. Their cooked

153 grain quality is acceptable to consumers, while Dinorado has greater volume increase and better 
154 palatability. UPL Ri-5 is higher yielding (average yield approximately $2.5-3.5 \mathrm{t} \mathrm{ha}^{-1}$ under

155 favorable conditions) compared to Dinorado (yield less than $2 \mathrm{tha}^{-1}$ up to $2.7 \mathrm{tha}^{-1}$ under the

156 same management practices). However, milled Dinorado had a local market price of more than a

157 dollar (in Philippine pesos, P45-50 $\mathrm{kg}^{-1}$, compared to UPL Ri-5 at P32-P35 kg-1). Higher

158 yielding UPL Ri-5 helps ensure farmers' household food security while the higher market value

159 of Dinorado provides additional income to the farmer. The average yield of Dinorado in Arakan

160 ranged from $<1$ to $1.5 \mathrm{t} \mathrm{ha}^{-1}$ while UPL Ri-5 produced 1 to $2 \mathrm{tha}^{-1}$. The national average yield of

161 upland rice was $<1$ to $1 \mathrm{tha}^{-1}$.

162 Mungbean is a preferred legume of local farmers in Arakan, with a market price similar

163 to Dinorado (R. F. Hondrade, personal observation). Average yields under favorable growing

164 conditions in the uplands ranged from 0.9 to $1.7 \mathrm{t} \mathrm{ha}^{-1}$. Farmers grow mungbean both for market

165 and household food consumption.

166 In addition to the analysis of grain yield described above, yield was also used to calculate

167 the corresponding land equivalent ratio (LER) for evaluating the rice mixture and the rice-

168 mungbean intercrops in each subplot. The LER for each subplot was calculated using the

169 following formula, illustrated for a two crop mixture.

170

$P_{1} \cdot \frac{\text { Yield }_{1} \text { in mixture }}{\text { Yield }_{1} \text { in monoculture }}+P_{2} \cdot \frac{\text { Yield }_{2} \text { in mixture }}{\text { Yield }_{2} \text { in monoculture }}$

171 where $\mathrm{P}_{\mathrm{i}}$ is the proportion of rows planted to Crop $\mathrm{i}$ in the subplot being considered (Table 1),

172 and Yield $\mathrm{i}_{\mathrm{i}}$ is the yield of Crop i calculated based on the dry (air- or sun-dried) weight per row.

173 The LER for the three crop mixtures (with Dinorado, UPL Ri-5, and mungbean) was calculated

174 similarly.

175 The LER for each mixture is a measure of how well the mixture or intercrop yield

176 compared to the monoculture yield. Pair-wise comparisons between the means of the LER for 
177 the four cropping treatments (Table 1) that included more than one type of crop were performed.

178 A one-tailed t-test was performed to see if there was evidence that the four LER means were

179 larger than 1.

180 Crop weed, disease, and insect evaluation

181 In each of the subplots, including the control, the weed biomass was weighed at the end of the

182 season. Common diseases were evaluated visually by an experienced disease observer, as

183 described below. A range of beneficial and pest arthropod species were also sampled within the

184 subplots, including the rice bug (Leptocorisa acuta). The following diseases and insect pests

185 were evaluated at crop maturity, where evaluation generally followed standard rating methods

186 (International Rice Research Institute 1996). For rice panicle blast (caused by Magnaporthe

187 oryzae), three categories of infection were recorded: no visible lesion, lesions on several pedicels

188 or secondary branches, or lesions on few primary branches or the middle part of the panicle axis.

189 Rice leaf blast (caused by Magnaporthe oryzae) was evaluated in 2007 and 2008, using a scale

190 of ten possible categories of infection (International Rice Research Institute 1996). Rice brown

191 spot (caused by Cochliobolus miyabeanus) was evaluated on a scale of 10 potential levels of

192 severity. Pod rot of mungbean (caused by Gluconobacter sp.) was evaluated in 2008 based on

193 percentage incidence, the percentage pods infected. Rice bug damage was evaluated in 2006 by

194 damage category.

195 Analysis of relative yield ranking of treatments, and stability of yield rank across

196 environments

197 To evaluate the relative yield and yield stability of the different cropping systems, we compared

198 cropping system performance across the different environments, in an analysis similar to the

199 Mundt (2002) analysis of wheat cultivar mixture performance. The analysis was performed as 
200 follows. The mean yield per row was computed for each treatment in each site for the three 201 years. For each of the twelve site-years, the weighted mean yield across the seven cropping 202 systems in Table 1 (excluding the control) was calculated, as an index of the quality of that site203 year as an environment for crop production ("environment index"). For each site-year, the rank 204 of each treatment mean yield was also computed $(1=$ lowest, $7=$ highest $)$, indicating the relative 205 performance of each treatment in each site-year. The performance of the intercropping systems was evaluated in two analyses, one based

207 solely on yield and one based on yield weighted by economic value. For the first, we used a 208 regression analysis to evaluate the relationship between the environment index (mean yield in each site-year) and the yield ranks for each treatment. The best intercropping system will have

210 the highest mean yield rank and will maintain its yield rank across environments. In the

211 regression analysis, a positive slope indicates higher performance rank in high yield

212 environments, while a negative slope indicates higher performance rank in low yield 213 environments. Lower P-values associated with the slope indicate stronger evidence that the

214 performance rank of a cropping treatment changes with environment. A relatively small mean

215 square error from the $\mathrm{F}$ test in the regression analysis indicates that the quality of the

216 environment explains most of the variability in performance rank of a cropping system. Second,

217 we performed the same type of analysis but with the crop yields weighted by their relative

218 economic value. The economic value of Dinorado and mungbean was approximately equivalent, 219 and $40 \%$ higher than the value of UPL Ri-5, based on typical valuation of these crops. Thus

220 relative economic weights were 1 for UPL Ri-5, 1.4 for Dinorado, and 1.4 for mungbean, and the 221 treatment mean yield per row was multiplied by these weights in the economic analysis. 


\section{RESULTS}

224 The responses for which the gamma distribution was used in SAS Proc GLIMMIX for 2006

225 were Dinorado and mungbean yield, disease levels for panicle blast and brown leaf spot, and rice

226 bug levels. In 2007-2008 the gamma distribution was used in analysis of UPL Ri-5 and levels of

227 brown spot, brown leaf spot, panicle blast, leaf blast, pod rot, and rice bug.

228 Rubber tree age effects

229 Rubber tree age did not have a significant effect on cropping system productivity (Table 3 ).

230 Although the mean subplot yield in one-year-old rubber sites was 1.5 times that in three-year-old

231 rubber sites, the variation among sites was very high (with yield 4.3 times higher in the highest

232 yielding one-year-old rubber site compared to the lowest yield one-year-old rubber site).

\section{Rice and mungbean yield responses to cropping system}

234 Rice yields per row were greater in intercropping systems than in monoculture in some cases,

235 although yields varied widely within and among years (Fig. 2 and Tables 2-5). There was a

236 tendency for rice yields to be higher when rice made up a smaller proportion of the intercrop

237 rows (Figs. 2 and S3). Dinorado yield responded significantly to intercropping treatments only

238 in $2006(\mathrm{p}=0.03)$, when Dinorado yield per area was significantly higher in $0.8 \mathrm{MB}$ than in

$2390.2 \mathrm{MB}$ (Tables 2 and 3). UPL Ri-5 yield also responded significantly to intercropping treatments

240 only in $2006(\mathrm{p}=0.001)$. UPL Ri-5 yield per area was significantly higher in $0.8 \mathrm{MB}$ compared

241 to the monoculture and RM in 2006 (Table 2). There were no significant treatment effects or

242 significant mean differences in pairwise comparisons for the two rice varieties in 2007 and 2008

243 (Tables 2 and 3). As expected, UPL Ri-5 yield was generally higher than Dinorado yield.

244 Mungbean yield did not respond significantly to intercropping treatments in 2006 (Table

245 2). Mungbean also showed a tendency for higher yield when mungbean made up a smaller 
246 proportion of the intercrop rows (Figs. 2 and S3). There was a significant treatment effect for

247 mungbean yield in 2007 and $2008(\mathrm{p}=0.03$; Table 3). There was a significant treatment $\mathrm{x}$ year

248 interaction $(\mathrm{p}=0.002)$. In 2007 and 2008 , mungbean yield per area was significantly higher in

$2490.2 \mathrm{MB}$ compared to $0.8 \mathrm{MB}$ (Table 2). Mungbean data were missing from one farm in 2006 and

250 there were also other cases of missing data that reduced the statistical power for mungbean

251 comparisons. One component of variability in mungbean response was the observed $90 \%$

252 severity of pod rot in one site (P. Roxas) in 2006.

253 Land equivalence ratios

254 The estimated LER for the rice mixture varied with year (Fig. 3; Table 4). The intercrop LER

255 estimate for $0.2 \mathrm{MB}$ was significantly greater than 1 in all three years, and $0.5 \mathrm{MB}$ and $0.8 \mathrm{MB}$

256 were also significantly greater than 1 in two out of three years. The intercropping treatments

257 differed significantly in their effect on LER in $2006(p=0.006$; Table 4). The mean LER was

258 significantly greater in RM and lower in $0.8 \mathrm{MB}$ in 2006 (Table 4). Also, the LER for RM was

259 significantly greater than one. In 2007 and 2008 there was a significant intercropping treatment

260 effect on LER $(p=0.03)$. Among the pairwise comparisons, the $0.5 \mathrm{MB}$ LER was significantly

261 greater than the RM LER. Also the 0.5MB LER mean was significantly greater than one, but the

262 mean of RM was not significantly less than 1.

263 Weed responses to cropping systems

264 Weeds commonly observed in the experiments were Ageratum conyzoides (Asteraceae),

265 Borreria laevis (Rubiaceae), Calopogonium mucunoides (Fabaceae), Chromolaena odorata

266 (Asteraceae), Ludwigia octovalvis (Onagraceae), Murdannia nudiflora (Commelinaceae), and

267 Rottboellia cochinchinensis (Poaceae), where A. conyzoides was particularly abundant. As

268 expected, all crop treatments resulted in lower weed biomass than the unplanted control (Table 
269 5). The mungbean monoculture had the lowest weed biomass in 2007-2008, and was

270 significantly lower than the weed biomass in the Dinorado monoculture and RM; however, in

2712006 the mungbean monoculture did not significantly reduce weed biomass (Table 5), probably

272 because of problems with mungbean establishment in that year. The intercropping treatment

273 effects were significant in both 2006 and 2007-2008. There was also a significant treatment by

274 year interaction in 2007-2008 (Table 5).

\section{Disease and insect responses to cropping treatment}

276 Disease and insect pests were present at low levels overall (Tables S10 and S12). Brown spot,

277 panicle blast, leaf blast, and rice bug were common enough in at least some years to be evaluated

278 for differential responses to the intercropping treatments. Brown spot (caused by Cochliobolus

279 miyabeanus) was generally more severe in Dinorado than in UPL Ri-5, and there was evidence

280 for decreased brown spot in Dinorado in the rice mixture and increased brown spot in Dinorado

281 in the 0.8MB intercrop in 2007-2008 (Table S12). Panicle blast (caused by Magnaporthe grisea)

282 was generally more severe in UPL Ri-5 compared to Dinorado in 2006 (Table S10), but more

283 severe in Dinorado than in UPL Ri-5 in 2007-2008 (Table S12). There was evidence that panicle

284 blast was higher in Dinorado in the $0.2 \mathrm{MB}$ intercrop and lower in the $0.5 \mathrm{MB}$ intercrop in 2006

285 compared to other treatments (Table S10). Leaf blast could be evaluated in 2007-2008. Leaf

286 blast severity was generally higher in Dinorado than in ULP Ri-5 (Table S12), but there were no

287 significant cropping treatment effects (Table S13). In 2007-2008 there was a year effect on

288 brown spot and leaf blast in UPL Ri-5 (Table S13). In 2006 there was an effect of rubber age on

289 panicle blast in UPL Ri-5, where older rubber trees were associated with higher disease (Table

290 S11). Pod rot of mungbean was observed at one site in P. Roxas in 2007-2008 where severity

291 reached $90 \%$, and the treatment effect was significant (Table S13). 
The rice bug, Leptocorisa acuta, could be evaluated in 2006 and was generally more

293 abundant in UPL Ri-5 than in Dinorado (Table S10). Rice bugs were significantly less common

294 in Dinorado in all intercropping systems compared to Dinorado monoculture, but were more

295 common in Dinorado in the rice mixture compared to the monoculture (Table S10). Other insect

296 pests observed in some sites were green leafhoppers (Nephotettix spp.), brown planthoppers

297 (Nilaparvata lugens), and grasshoppers. The most commonly observed beneficial insects were

298 spiders, wasps, red ants, and lady bugs, but these were observed too infrequently to allow

299 statistical comparison of treatment effects.

300 Yield rank and stability

301 In the analysis of yield rank and stability (Table 6), the monoculture UPL Ri-5 had the highest

302 mean yield rank, with little evidence $(\mathrm{P}=0.15)$ for a positive slope, and mean square error 1.95.

303 The second highest mean yield rank was for the rice mixture (RM, 4 rows of Dinorado and 6

304 rows of UPL Ri-5), with a relatively high mean square error 2.53 indicating higher variability

305 than observed for UPL Ri-5. The next highest ranked cropping systems were the 0.5 and $0.2 \mathrm{MB}$

306 intercropping systems, with similar performance. Comparing all the treatments, the monoculture

307 mungbean (MB) treatment had the lowest mean yield rank (1.9), a negative slope (-0.000377)

308 and a relatively high mean square error (3.21) reflecting yield loss to water-logging problems at

309 some sites, particularly in 2006.

310 The yield rank and stability weighted by economic values (Table 7) showed similar

311 trends. UPL Ri-5 still had the highest ranked performance, but among the weighted ranks there

312 was stronger evidence $(\mathrm{P}=0.07)$ for a positive slope, indicating that the relative performance of

313 UPL Ri-5 was higher in environments with higher mean yield. The mean performance of the 0.5

314 MB intercropping system and the Dinorado monoculture was higher when weighted by 
315 economic values, tied for second highest rank. For the $0.5 \mathrm{MB}$ system, there was not evidence

316 for a non-zero slope, thus not evidence for a change in yield rank across environments $(\mathrm{P}=0.3)$.

317 For the Dinorado monoculture, there was evidence for a positive slope $(\mathrm{P}=0.03)$, indicating

318 Dinorado yield was less stable in poorer environments (Fig. S5). The Dinorado monoculture

319 also had a somewhat higher MSE than the 0.5 MB intercropping system.

320

321 DISCUSSION

322 Crop production in rubber tree plantations appears to be a viable approach for increasing local

323 food production where young rubber plantations are common, and potentially for increasing

324 local household food security. As rubber trees age, the mean yield of crops intercropped with

325 rubber may go down, but the difference between crop yield in one-year-old rubber and three-

326 year-old rubber was small relative to the overall variability in yield. Farmers in the area of these

327 experiments continued to plant rice, mungbean, peanut, or corn in zero- to two-year-old rubber,

328 although they did not commonly use intercropping of crop species, and the practice of planting

329 crop species between tree rows has also been adopted in palm oil plantations (R. F. Hondrade,

330 personal observation). Two rice varieties are commonly used, a higher yielding variety and either

331 Dinorado or another traditional variety, depending on market demand (R. F. Hondrade, personal

332 observation).

333 Extension programs can help make farmers aware of the range of options for

334 intercropping in tree crops like rubber. Mindanao had relatively higher rates of technological

335 change in rice production than some other areas of the Philippines, with factors such as

336 investment in infrastructure, farm mechanization, and adoption of modern rice varieties (Umetsu

337 et al. 2003). Planting rice with leguminous tree species has been proposed for upland rice 
338 production in eroded areas of northern Mindanao, with reports of increased UPL Ri-5 yield in

339 eroded sites (MacLean et al. 2003). Farmers in Sri Lanka were more likely to adopt rubber

340 intercropping if they had more extension contacts and higher education (Herath \& Takeya 2003).

341 Intercropping with tea has been recommended to improve income in the pre-tapping phase for

342 farmers in Sri Lanka, where intercropping in rubber can be an important part of household

343 strategies with reported benefits both before and during rubber production (Rodrigo et al. 2001).

344 Farmers were more likely to adopt this system if they had incomes above a minimal level, if their

345 income was based solely on their farm, and if the majority of land was suitable for tea

346 cultivation. Technical knowledge of how to intercrop tea and rubber was identified as a limiting

347 factor in adoption (Iqbal et al. 2006).

348 In comparing the performance of the seven cropping system treatments (Table 1), a

349 monoculture of UPL Ri-5 had the highest mean yield rank, with or without weighting for

350 economic value per unit production. However there was some evidence that the performance of

351 UPL Ri-5 was lower in poorer environments, where household food security may be more

352 problematic. When considering yield weighted for economic value, the next highest mean yield

353 rank was the tied 0.5 MB intercropping system and the Dinorado monoculture, where the $0.5 \mathrm{MB}$

354 system appeared somewhat more stable (having a non-significant slope in response across

355 environments and lower MSE). The poorer performance of some cropping systems was a result

356 of poor mungbean establishment at some sites, which could potentially be improved through

357 greater farmer experience in mungbean production. The tendency for crops to yield higher when

358 they made up less than $50 \%$ of a cropping system suggests there may be more opportunities for

359 developing useful intercropping systems. 
361 levels present an interesting question in their own right. In fact this region of Mindanao has a

362 reputation for having low disease pressure, where the reasons for this are not entirely clear.

363 There have been outbreaks of bacterial blight and blast in Mindanao, which might be explained

364 in part by widespread planting of a single rice cultivar (R. F. Hondrade, personal

365 communication). Part of the popularity of Dinorado may be due to its relative disease resistance,

366 in addition to higher economic value. UPL Ri-5 produced higher yields than Dinorado, even

367 when weighted for economic value. There was a tendency for UPL Ri-5 to have lower disease

368 levels when in the mixture with the more resistant Dinorado, consistent with other reports for

369 rice disease in mixtures (Meung et al. 2003; Zhu et al. 2000). There is the potential for

370 mungbean to change the microenvironment for rice, but the difficulties in mungbean

371 establishment may have made this harder to interpret in this experiment. Microclimate (canopy

372 moisture) has probably played an important role in the success of some rice mixtures, where

373 taller susceptible rice plants surrounded by shorter resistant plants experience less leaf surface

374 moisture and so lower disease development (Zhu et al. 2005). Environmental differences among

375 farms may alter the effects of crop mixtures due to altered competition, or to altered epidemic

376 processes (Garrett et al. 2009). Weed species composition in upland rice is particularly variable

377 compared to other rice production systems, and particularly challenging. Imperata control has

378 been identified as an important component of management for Indonesian rubber (Grist \& Menz

379 1996). Potential management by planting rubber at high densities to compete with weeds

380 presents a trade-off in that high-density rubber will making incorporation of food crops more

381 challenging. 
383 a range of benefits including increased household food security and wider ecosystem services

384 (Cheatham et al. 2009; Jose 2009; Swift et al. 2004). For example, there is the potential to

385 develop longer-term rubber intercropping systems, to buffer fluctuating rubber prices (Cramb et

386 al. 2009; Nath et al. 2013), by altering rubber tree planting arrangements to allow greater

387 resource availability for other crops (Rodrigo et al. 2004), depending on the stage of

388 development of the local systems (Barlow 1997; Dressler \& Pulhin 2010) and the availability of

389 other options for income (Dressler \& Fabinyi 2011; Langenberger et al. 2016; Neyra-Cabatac et

390 al. 2012). In such a system, a managed understory can be integrated in place of additional trees.

391 Upland rice presents a trade-off, because it has an important role in crop production for resource-

392 poor farmers, but can present an important environmental cost if fragile ecosystems are

393 converted for upland rice production. If lands are in plantation production, anyway, the

394 environmental cost of adding upland rice is reduced. It will be useful to learn more about the

395 probably complicated relationship between local rates of crop production in rubber plantations

396 and household food security. Identifying more productive intercropping systems may help to

397 promote useful implementation.

398

399 ACKNOWLEDGEMENTS

400 We appreciate technical assistance from M. Pinili, input from S. G. Elarde, G. Lee, and D.

401 Paranagama, and comments from PeerJ reviewers that led to improvements in the manuscript.

402 We appreciate the contributions of the farmer-cooperators who maintained the field trials on

403 their farms: Sim Arelolo, Rodolfo Bosque, Edwin Cainggoy, Wilson Espartero, Alex Oreta, and 
404

405

406

407

408

409

410

411

412

413

414

415

416

417

418

419

420

421

422

423

424

425

426

427

428

429

430

431

432

433

434

435

436

437

438

439

440

441

442

Arsenia Testado in 2006; W. Espartero, Rodrigo Pajanila, Romeo Pedroso, and A. Oreta in 2007 and 2008.

\section{REFERENCES}

Barlow C. 1997. Growth, structural change and plantation tree crops: The case of rubber. World Development 25:1589-1607. 10.1016/s0305-750x(97)00059-4

Cheatham MR, Rouse MN, Esker PD, Ignacio S, Pradel W, Raymundo R, Sparks AH, Forbes GA, Gordon TR, and Garrett KA. 2009. Beyond yield: Plant disease in the context of ecosystem services. Phytopathology 99:1228-1236. Doi 10.1094/Phyto-99-111228

Cramb RA, Colfer CJP, Dressler W, Laungaramsri P, Le QT, Mulyoutami E, Peluso NL, and Wadley RL. 2009. Swidden transformations and rural livelihoods in Southeast Asia. Human Ecology 37:323-346. 10.1007/s10745-009-9241-6

Dove MR. 1993. Smallholder rubber and swidden agricutlure in Borneo - a sustainable adaptation to the ecology and economy of the tropical forest. Economic Botany 47:136147. $10.1007 / \mathrm{bf02862016}$

Dressler W, and Pulhin J. 2010. The shifting ground of swidden agriculture on Palawan Island, the Philippines. Agriculture and Human Values 27:445-459. 10.1007/s10460-009-9239-0

Dressler WH, and Fabinyi M. 2011. Farmer gone fish'n? Swidden decline and the rise of grouper fishing on Palawan Island, the Philippines. Journal of Agrarian Change 11:536555. 10.1111/j.1471-0366.2011.00309.x

Esekhade TU, Orimoloye JR, Ugwa IK, and Idoko SO. 2003. Potentials of multiple cropping systems in young rubber plantations. Journal of Sustainable Agriculture 22:79-94. 10.1300/J064v22n04_07

Finckh MR, Gacek ES, Goyeau H, Lannou C, Merz U, Mundt CC, Munk L, Nadziak J, Newton AC, de Vallavieille-Pope C, and Wolfe MS. 2000. Cereal variety and species mixtures in practice, with emphasis on disease resistance. Agronomie 20:813-837.

Fox J, and Castella JC. 2013. Expansion of rubber (Hevea brasiliensis) in Mainland Southeast Asia: what are the prospects for smallholders? Journal of Peasant Studies 40:155-170. 10.1080/03066150.2012.750605

Garrett KA, and Mundt CC. 1999. Epidemiology in mixed host populations. Phytopathology 89:984-990.

Garrett KA, Zúñiga LN, Roncal E, Forbes GA, Mundt CC, Su Z, and Nelson RJ. 2009. Intraspecific functional diversity in hosts and its effect on disease risk across a climatic gradient. Ecological Applications 19:1868-1883.

Grist PG, and Menz KM. 1996. The economics of Imperata control in Indonesian smallholder rubber (Hevea spp.) plantations using bioeconomic modelling. Tropical Agriculture 73:320-324. 
443

444

445

446

447

448

449

450

451

452

453

454

455

456

457

458

459

460

461

462

463

464

465

466

467

468

469

470

471

472

473

474

475

476

477

478

479

480

481

482

483

484

485

486

487

488

Guo ZM, Zhang YQ, Deegen P, and Uibrig H. 2006. Economic analyses of rubber and tea plantations and rubber-tea intercropping in Hainan, China. Agroforestry Systems 66:117127. 10.1007/s10457-005-4676-2

Gurr GM, Lu Z, Zheng X, Xu H, Zhu P, Chen G, Yao X, Cheng J, Zhu Z, and Catindig JL. 2016. Multi-country evidence that crop diversification promotes ecological intensification of agriculture. Nature Plants 2:16014.

Herath P, and Takeya H. 2003. Factors determining intercropping by rubber smallholders in Sri Lanka: a logit analysis. Agricultural Economics 29:159-168. 10.1016/s01695150(03)00045-8

International Rice Research Institute. 1996. Standard Evaluation System for Rice, 4th edition. Metro Manila, Philippines: International Rice Research Institute.

Iqbal SMM, Ireland CR, and Rodrigo VHL. 2006. A logistic analysis of the factors determining the decision of smallholder farmers to intercrop: A case study involving rubber-tea intercropping in Sri Lanka. Agricultural Systems 87:296-312. 10.1016/j.agsy.2005.02.002

Jessy MD, Joseph P, and George S. 2016. Possibilities of diverse rubber based agroforestry systems for smallholdings in India. Agroforestry Systems:in press. 10.1007/s10457-0169953-8

Jose S. 2009. Agroforestry for ecosystem services and environmental benefits: an overview. Agroforestry Systems 76:1-10. 10.1007/s10457-009-9229-7

Josol MRC, and Montefrio MJF. 2013. Understanding the resilience of swidden agroecosystems interacting with rubber and oil palm production regimes in the Philippines. Agroecology and Sustainable Food Systems 37:812-833. 10.1080/21683565.2013.775540

Khan ZR, Pickett JA, Berg Jvd, Wadhams LJ, and Woodcock CM. 2000. Exploiting chemical ecology and species diversity: stem borer and striga control for maize and sorghum in Africa. Pest Management Science 56:957-962.

Langenberger G, Cadisch G, Martin K, Min S, and Waibel H. 2016. Rubber intercropping: a viable concept for the 21st century? Agroforestry Systems:in press. 10.1007/s10457-0169961-8

Li P, Feng ZM, Jiang LG, Liao CH, and Zhang JH. 2014. A Review of swidden agriculture in Southeast Asia. Remote Sensing 6:1654-1683. 10.3390/rs6021654

MacLean RH, Litsinger JA, Moody K, Watson AK, and Libetario EM. 2003. Impact of Gliricidia sepium and Cassia spectabilis hedgerows on weeds and insect pests of upland rice. Agriculture Ecosystems \& Environment 94:275-288. 10.1016/s01678809(02)00033-6

Manivong V, and Cramb RA. 2008. Economics of smallholder rubber expansion in Northern Laos. Agroforestry Systems 74:113-125. 10.1007/s10457-008-9136-3

Mertz O, Egay K, Bruun TB, and Colding TS. 2013. The last swiddens of Sarawak, Malaysia. Human Ecology 41:109-118. 10.1007/s10745-012-9559-3

Meung H, Zhu YY, Revilla-Molina I, Fan JX, Chen HR, Pangga I, Vera Cruz C, and Mew TW. 2003. Using genetic diversity to achieve sustainable rice disease management. Plant Disease 87:1156-1169.

Montefrio MJF, and Sonnenfeld DA. 2013. Global-local tensions in contract farming of biofuel crops involving indigenous communities in the Philippines. Society \& Natural Resources 26:239-253. 10.1080/08941920.2012.682114 
489

490

491

492

493

494

495

496

497

498

499

500

501

502

503

504

505

506

507

508

509

510

511

512

513

514

515

516

517

518

519

520

521

522

523

524

525

526

527

528

529

530

531

532

Mundt CC. 2002. Performance of wheat cultivars and cultivar mixtures in the presence of Cephalosporium stripe. Crop Protection 21:93-99. 10.1016/s0261-2194(01)00067-9

Nath TK, Inoue M, and De Zoysa M. 2013. Small-scale rubber planting for enhancement of people's livelihoods: A comparative study in three South Asian countries. Society \& Natural Resources 26:1066-1081. 10.1080/08941920.2013.779342

Neyra-Cabatac NM, Pulhin JM, and Cabanilla DB. 2012. Indigenous agroforestry in a changing context: The case of the Erumanen ne Menuvu in Southern Philippines. Forest Policy and Economics 22:18-27. 10.1016/j.forpol.2012.01.007

Pathiratna LSS, and Perera MKP. 2006. Effect of plant density on bark yield of cinnamon intercropped under mature rubber. Agroforestry Systems 68:123-131. 10.1007/s10457006-9003-z

Penot E, and Ollivier I. 2009. Rubber tree intercropping with food crops, perennail, fruit and tree crops: several examples in Asia, Africa and America. Bois Et Forets Des Tropiques:67-82.

Rajasekharan $\mathbf{P}$, and Veeraputhran S. 2002. Adoption of intercropping in rubber smallholdings in Kerala, India: a tobit analysis. Agroforestry Systems 56:1-11. 10.1023/a:1021199928069

Rodrigo VHL, Silva TUK, and Munasinghe ES. 2004. Improving the spatial arrangement of planting rubber (Hevea brasiliensis Muell. Arg.) for long-term intercropping. Field Crops Research 89:327-335. 10.1016/j.fcr.2004.02.013

Rodrigo VHL, Stirling CM, Silva TUK, and Pathirana PD. 2005. The growth and yield of rubber at maturity is improved by intercropping with banana during the early stage of rubber cultivation. Field Crops Research 91:23-33. 10.1016/j.jfcr.2004.05.005

Rodrigo VHL, Thenakoon S, and Stirling CM. 2001. Priorities and objectives of smallholder rubber growers and the contribution of intercropping to livelihood strategies: a case study from Sri Lanka. Outlook on Agriculture 30:261-266.

Schroth G, Salazar E, and Da Silva JP. 2001. Soil nitrogen mineralization under tree crops and a legume cover crop in multi-strata agroforestry in central Amazonia: Spatial and temporal patterns. Experimental Agriculture 37:253-267.

Swift MJ, Izac AMN, and van Noordwijk M. 2004. Biodiversity and ecosystem services in agricultural landscapes - are we asking the right questions? Agriculture Ecosystems \& Environment 104:113-134. 10.1016/j.agee.2004.01.013

Umetsu C, Lekprichakul T, and Chakravorty U. 2003. Efficiency and technical change in the Philippine rice sector: A Malmquist total factor productivity analysis. American Journal of Agricultural Economics 85:943-963. 10.1111/1467-8276.00499

van Noordwijk M, Cadisch G, and Ong CK. 2004. Below-ground Interactions in Tropical Agroecosystems: Concepts and Models with Multiple Plant Components: CABI Publishing.

van Vliet N, Mertz O, Heinimann A, Langanke T, Pascual U, Schmook B, Adams C, Schmidt-Vogt D, Messerli P, Leisz S, Castella JC, Jorgensen L, Birch-Thomsen T, Hett C, Bruun TB, Ickowitz A, Vu KC, Yasuyuki K, Fox J, Padoch C, Dressler W, and Ziegler AD. 2012. Trends, drivers and impacts of changes in swidden cultivation in tropical forest-agriculture frontiers: A global assessment. Global Environmental ChangeHuman and Policy Dimensions 22:418-429. 10.1016/j.gloenvcha.2011.10.009 
533

534

535

536

537

538

539

540

541

542

543

544

545

546

547
Vongvisouk T, Mertz O, Thongmanivong S, Heinimann A, and Phanvilay K. 2014. Shifting cultivation stability and change: Contrasting pathways of land use and livelihood change in Laos. Applied Geography 46:1-10. 10.1016/j.apgeog.2013.10.006

Weinberger K. 2013. Home and community gardens in Southeast Asia: potential and opportunities for contributing to nutrition-sensitive food systems. Food Security 5:847856. 10.1007/s12571-013-0299-Z

Wu J, Liu W, and Chen C. 2016. Can intercropping with the world's three major beverage plants help improve the water use of rubber trees? Journal of Applied Ecology:in press. $10.1111 / 1365-2664.12730$

Zhu YY, Chen HR, Fan JH, Wang YY, Li Y, Chen JB, Fan JX, Yang SS, Hu LP, Leung H, Mew TW, Teng PS, Wang ZH, and Mundt CC. 2000. Genetic diversity and disease control in rice. Nature 406:718-722. 10.1038/35021046

Zhu YY, Fang H, Wang YY, Fan JX, Yang SS, Mew TW, and Mundt CC. 2005. Panicle blast and canopy moisture in rice cultivar mixtures. Phytopathology 95:433-438. 10.1094/phyto-95-0433 


\section{Figure captions}

550

551 Figure 1. Planting rice and mungbean in an experimental site in Mindanao with three-year-old

552 rubber.

553

554 Figure 2. Yield (g/row) of two rice cultivars (Dinorado and UPL Ri-5) and mungbean grown 555 between rubber tree rows in a Mindanao plantation. The rice and mungbean were grown in 556 monoculture and in a set of mixture and intercropping treatments (Table 1). In the boxplots, the

557 white bar indicates the median across all farms, the boundaries of the box indicate the $25^{\text {th }}$ and $55875^{\text {th }}$ percentiles, the extent of the dotted lines indicate the minimum and maximum, and circles 559 beyond these indicate more unusual values.

560

561 Figure 3. The Land Equivalent Ratio (LER) for a rice mixture and three intercropping systems

562 (Table 1) in three years across all rubber plantations studied. In the boxplots, the white bar

563 indicates the median across all farms, the boundaries of the box indicate the $25^{\text {th }}$ and $75^{\text {th }}$

564 percentiles, the extent of the dotted lines indicate the minimum and maximum, and circles

565 beyond these indicate more unusual values. These values were not weighted by the relative 566 economic value of different crops. 


\section{Table 1 (on next page)}

Experimental treatments planted in subplots between rows of rubber trees in farmers' fields in Mindanao 
1 Table 1. Experimental treatments planted in subplots between rows of rubber trees in farmers'

2 fields in Mindanao

3

\begin{tabular}{|c|c|c|c|c|}
\hline \multirow[t]{2}{*}{$\begin{array}{l}\text { Treatment } \\
\text { abbrev. }\end{array}$} & \multirow{2}{*}{$\begin{array}{l}\text { Subplot treatment between } \\
\text { rubber trees } \\
\text { (Applied to subplot with } 10 \text { rows) }\end{array}$} & Crops ap! & $\begin{array}{l}\text { aring in ea } \\
\text { (rows) }\end{array}$ & treatment \\
\hline & & Dinorado & UPL Ri-5 & Mungbean \\
\hline Control & No crops planted & & & \\
\hline Dinorado & 10 rows rice cv. Dinorado (D) & 10 & & \\
\hline UPL Ri-5 & 10 rows rice cv. UPL Ri-5 (U) & & 10 & \\
\hline $\mathrm{RM}$ & $\begin{array}{l}\text { Rice mixture: } 2 \text { rows } \mathrm{D}, 3 \text { rows } \mathrm{U} \text {, } \\
\text { repeated twice }\end{array}$ & 4 & 6 & \\
\hline $0.5 \mathrm{MB}$ & $\begin{array}{l}2 \text { rows } \mathrm{D}, 3 \text { rows } \mathrm{U}, 5 \text { rows } \\
\text { mungbeans }(\mathrm{MB})\end{array}$ & 2 & 3 & 5 \\
\hline $0.8 \mathrm{MB}$ & $\begin{array}{l}4 \text { rows } M, 2 \text { rows }^{\mathrm{a}} \mathrm{U}+\mathrm{D}, 4 \text { rows } \\
\mathrm{MB}\end{array}$ & 1 & 1 & 8 \\
\hline $0.2 \mathrm{MB}$ & $2 \mathrm{D}, 2 \mathrm{U}, 2 \mathrm{D}, 2 \mathrm{U}, 2 \mathrm{MB}$ & 4 & 4 & 2 \\
\hline MB & 10 rows mungbeans $(\mathrm{MB})$ & & & 10 \\
\hline
\end{tabular}

4 aUPL Ri-5 and Dinorado in fractions of rows 


\section{Table 2 (on next page)}

Yield (grams/row) of mungbean and two rice cultivars (Dinorado and UPL Ri-5) for eight cropping treatments (Table 1), from intercropping systems in rubber plantations in Mindanao. 
1 Table 2. Yield (grams/row) of mungbean and two rice cultivars (Dinorado and UPL Ri-5) for

2 eight cropping treatments (Table 1), from intercropping systems in rubber plantations in

3 Mindanao.

4

\begin{tabular}{|c|c|c|c|c|c|}
\hline \multirow{2}{*}{ Crops } & \multirow{2}{*}{ Treatment } & \multicolumn{2}{|c|}{2006 Yield } & \multicolumn{2}{|c|}{ 2007-2008 Yield } \\
\hline & & Mean & $(\mathrm{SD})$ & Mean & $(\mathrm{SD})$ \\
\hline \multirow{5}{*}{ Dinorado } & Monoculture & $487^{\mathrm{ab}}$ & 195 & $697^{\mathrm{a}}$ & 186 \\
\hline & $\mathrm{RM}$ & $524^{\mathrm{ab}}$ & 195 & $653^{\mathrm{a}}$ & 186 \\
\hline & $0.5 \mathrm{MB}$ & $626^{\mathrm{ab}}$ & 195 & $1075^{\mathrm{a}}$ & 186 \\
\hline & $0.8 \mathrm{MB}$ & $762^{\mathrm{a}}$ & 195 & $878^{a}$ & 186 \\
\hline & $0.2 \mathrm{MB}$ & $470^{\mathrm{b}}$ & 195 & $643^{\mathrm{a}}$ & 186 \\
\hline \multirow{5}{*}{ UPL Ri-5 } & Monoculture & $651^{\mathrm{a}}$ & 226 & $1053^{a}$ & 185 \\
\hline & RM & $605^{\mathrm{a}}$ & 226 & $928^{a}$ & 185 \\
\hline & $0.5 \mathrm{MB}$ & $790^{\mathrm{ab}}$ & 226 & $1044^{\mathrm{a}}$ & 185 \\
\hline & $0.8 \mathrm{MB}$ & $928^{b}$ & 226 & $1252^{\mathrm{a}}$ & 185 \\
\hline & $0.2 \mathrm{MB}$ & $668^{a b}$ & 226 & $1065^{\mathrm{a}}$ & 185 \\
\hline \multirow{4}{*}{ Mungbean } & Monoculture & $218^{\mathrm{a}}$ & 75 & $367^{\mathrm{ab}}$ & 31 \\
\hline & $0.5 \mathrm{MB}$ & $178^{\mathrm{a}}$ & 75 & $397^{\mathrm{ab}}$ & 31 \\
\hline & $0.8 \mathrm{MB}$ & $293^{\mathrm{a}}$ & 75 & $348^{a}$ & 31 \\
\hline & $0.2 \mathrm{MB}$ & $193^{\mathrm{a}}$ & 75 & $430^{b}$ & 31 \\
\hline
\end{tabular}

5 Treatments RM, 0.5MB, 0.8MB and $0.2 \mathrm{MB}$ refer to the intercropping treatments in Table 2.

6 Superscripts a, b: if treatments are marked by the same letters, then there is no significant 
7 difference in the pair-wise comparison. If the means contain different letter, then there is a 8 significant difference at the 0.05 level. 


\section{Table 3(on next page)}

Treatment effects and results of an AOV for yield (grams/row) of mungbean and two rice cultivars (Dinorado and UPL Ri-5) from intercropping systems (Table 1 ) in rubber plantations in Mindanao. 
1 Table 3. Treatment effects and results of an AOV for yield (grams/row) of mungbean and two

2 rice cultivars (Dinorado and UPL Ri-5) from intercropping systems (Table 1) in rubber

3 plantations in Mindanao.

4

\begin{tabular}{|c|c|c|c|c|}
\hline \multirow{2}{*}{ Crops } & \multicolumn{2}{|c|}{2006 yield } & \multicolumn{2}{|c|}{ 2007-2008 yield } \\
\hline & Effect & F-test P-values & Effect & F-test P-values \\
\hline \multirow{4}{*}{ Dinorado } & Treatment & 0.03 & Treatment & 0.51 \\
\hline & Rubber age & 0.53 & Year & 0.21 \\
\hline & Trt*Rubber age & 0.85 & Trt*Year & 0.73 \\
\hline & Treatment & 0.001 & Treatment & 0.88 \\
\hline \multirow[t]{3}{*}{ UPL Ri-5 } & Rubber age & 0.84 & Year & 0.15 \\
\hline & Trt*Rubber age & 0.77 & Trt*Year & 0.07 \\
\hline & Treatment & 0.45 & Treatment & 0.03 \\
\hline \multirow[t]{2}{*}{ Mungbean } & Rubber age & 0.53 & Year & 0.33 \\
\hline & Trt*Rubber age & 0.43 & Trt*Year & 0.002 \\
\hline
\end{tabular}

Bold P-values are significant at the 0.05 level.

6 


\section{Table 4 (on next page)}

The land equivalent ratio (LER) for eight cropping systems (Table 1) of mungbean and two rice cultivars (Dinorado and UPL Ri-5), from intercropping systems in rubber plantations in Mindanao.

Results are given for a t-test of whether the LER is greater than 1 . 
1 Table 4. The land equivalent ratio (LER) for eight cropping systems (Table 1) of mungbean and 2 two rice cultivars (Dinorado and UPL Ri-5), from intercropping systems in rubber plantations in 3 Mindanao. Results are given for a t-test of whether the LER is greater than 1.

4

\begin{tabular}{|c|c|c|c|c|c|c|c|c|}
\hline \multicolumn{4}{|c|}{2006} & \multicolumn{4}{|c|}{$2007-2008$} & \multirow{2}{*}{$\begin{array}{l}\text { Overall } \\
\text { Mean }\end{array}$} \\
\hline $\begin{array}{l}\text { Treatment } \\
\text { and effects }\end{array}$ & Mean & (SD) & $\begin{array}{l}\text { t-test p- } \\
\text { value }\end{array}$ & $\begin{array}{l}\text { Treatment } \\
\text { and effects }\end{array}$ & Mean & (SD) & $\begin{array}{l}\text { t-test p- } \\
\text { value }\end{array}$ & \\
\hline $\mathrm{RM}$ & $1.53^{b}$ & 0.14 & 0.0007 & $\mathrm{RM}$ & $0.93^{\mathrm{a}}$ & 0.08 & 0.19 & 1.23 \\
\hline $0.5 \mathrm{MB}$ & $1.13^{\mathrm{ab}}$ & 0.14 & 0.18 & $0.5 \mathrm{MB}$ & $1.21^{\mathrm{b}}$ & 0.08 & 0.009 & 1.17 \\
\hline $0.8 \mathrm{MB}$ & $0.99^{a}$ & 0.14 & 0.47 & $0.8 \mathrm{MB}$ & $1.12^{\mathrm{ab}}$ & 0.08 & 0.08 & 1.05 \\
\hline $0.2 \mathrm{MB}$ & $1.23^{\mathrm{ab}}$ & 0.14 & 0.06 & $0.2 \mathrm{MB}$ & $1.13^{\mathrm{ab}}$ & 0.08 & 0.06 & 1.18 \\
\hline Trt effect & & & & Trt effect & & & & \\
\hline P-value & 0.006 & - & - & P-value & 0.03 & - & - & - \\
\hline Age effect & & & & Year effect & & & & \\
\hline $\mathrm{P}$-value & 0.50 & - & - & P-value & 0.05 & - & - & - \\
\hline Trt*Age & & & & Trt*Year & & & & \\
\hline $\mathrm{P}$-value & 0.22 & - & - & $\mathrm{P}$-value & 0.70 & - & - & - \\
\hline
\end{tabular}

5 The Trt effect refers to the four treatments RM, 0.5MB, 0.8MB and 0.2MB. Trt*Age is the four

6 treatments and the rubber age interaction in year 2006. Trt*Year is the four treatments and year

7 interaction in 2007-2008. Superscripts a, b: if the means contain the same letters, then there is no

8 significant difference in the pair-wise comparison. If the means contain different letters, then

9 there is a significant difference at the 0.05 level. Bold $p$ values are significant at the 0.05 level. 


\section{Table 5 (on next page)}

Weed biomass in eight cropping systems (Table 1 ) of mungbean and two rice cultivars (Dinorado and UPL Ri-5), from intercropping systems in rubber plantations in Mindanao.

The square root transformation was used in analysis, where the original unit for weed biomass was $\mathrm{g} / \mathrm{m}^{2}$. 
1 Table 5. Weed biomass in eight cropping systems (Table 1) of mungbean and two rice cultivars

2 (Dinorado and UPL Ri-5), from intercropping systems in rubber plantations in Mindanao. The

3 square root transformation was used in analysis, where the original unit for weed biomass was

$4 \mathrm{~g} / \mathrm{m}^{2}$.

5

6

$\underline{2006} \underline{2007-2008}$

Treatment and effects Mean (SD) Mean (SD)

\begin{tabular}{ccccc}
\hline Control & $31.2^{\mathrm{a}}$ & 2.5 & $24.6^{\mathrm{a}}$ & 1.4 \\
Dinorado & $14.5^{\mathrm{b}}$ & 2.5 & $15.5^{\mathrm{b}}$ & 1.4 \\
UPL Ri-5 & $10.8^{\mathrm{b}}$ & 2.5 & $13.7^{\mathrm{bc}}$ & 1.4 \\
$\mathrm{RM}$ & $11.9^{\mathrm{b}}$ & 2.5 & $15.1^{\mathrm{bcd}}$ & 1.4 \\
$0.5 \mathrm{MB}$ & $13.2^{\mathrm{b}}$ & 2.5 & $13.9^{\mathrm{bcd}}$ & 1.4 \\
$0.8 \mathrm{MB}$ & $13.3^{\mathrm{b}}$ & 2.5 & $13.1^{\mathrm{bcd}}$ & 1.4 \\
$0.2 \mathrm{MB}$ & $12.2^{\mathrm{b}}$ & 2.5 & $12.6^{\mathrm{cd}}$ & 1.4 \\
$\mathrm{MB}$ & $14.7^{\mathrm{b}}$ & 2.5 & $11.7^{\mathrm{c}}$ & 1.4 \\
\hline
\end{tabular}

Trt effect

P-value $\quad<0.01-<0.01-$

Age effect

P-value $\quad 0.36-0.09-$

Trt*Age

P-value $\quad 0.78 \quad<\mathbf{0 . 0 1}-$

7 Eight intercropping treatments (Table 2) were compared. The effects of treatments with the same

8 letter superscript are not significantly different. Bold p-values are significant at the 0.05 level. 


\section{Table 6(on next page)}

An analysis comparing the yield performance and stability of intercropping system treatments (Table 1) of mungbean and two rice cultivars (Dinorado and UPL Ri-5), in rubber plantations in Mindanao.

Regression analysis using the mean yield of each treatment for each site as predictor, and yield ranks ( $1=$ lowest, $7=$ highest) of each treatment as response. 
1 Table 6. An analysis comparing the yield performance and stability of intercropping system

2 treatments (Table 1) of mungbean and two rice cultivars (Dinorado and UPL Ri-5), in rubber

3 plantations in Mindanao. Regression analysis using the mean yield of each treatment for each

4 site as predictor and yield ranks ( $1=$ lowest, $7=$ highest $)$ of each treatment as response.

5

\begin{tabular}{l|cccc}
\hline Treatment & Mean Rank & Slope & P-values $^{\mathrm{a}}$ & $\mathrm{MSE}^{\mathrm{b}}$ \\
\hline UPL Ri-5 & 6.3 & 0.0025 & 0.15 & 1.95 \\
RM & 5 & 0.0025 & 0.20 & 2.53 \\
$0.5 \mathrm{MB}$ & 4.5 & -0.0022 & 0.13 & 1.34 \\
$0.2 \mathrm{MB}$ & 4.2 & -0.0001 & 0.93 & 0.97 \\
Dinorado & 3.8 & 0.0038 & 0.06 & 2.33 \\
$0.8 \mathrm{MB}$ & 2.4 & -0.0027 & 0.07 & 1.33 \\
MB & 1.9 & -0.0038 & 0.10 & 3.21 \\
\hline
\end{tabular}

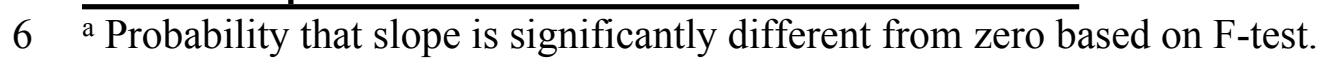

$7 \quad \mathrm{~b}$ Mean square error of the regression.

8 


\section{Table 7 (on next page)}

An analysis comparing the yield performance (weighted by relative economic value) and stability of intercropping system treatments (Table 1) of mungbean and two rice cultivars (Dinorado and UPL Ri-5), in rubber plantations in Mindanao.

Regression analysis using the mean yield of each treatment for each site as predictor and yield ranks ( $1=$ lowest, $7=$ highest) of each treatment as response. 
1 Table 7. An analysis comparing the yield performance (weighted by relative economic value)

2 and stability of intercropping system treatments (Table 1) of mungbean and two rice cultivars

3 (Dinorado and UPL Ri-5), in rubber plantations in Mindanao. Regression analysis using the

4 mean yield of each treatment for each site as predictor and yield ranks $(1=$ lowest, $7=$ highest $)$

5 of each treatment as response.

6

\begin{tabular}{l|cccc}
\hline Treatment & Mean Rank & Slope & P values $^{\mathrm{a}}$ & $\mathrm{MSE}^{\mathrm{b}}$ \\
\hline UPL Ri-5 & 5.3 & 0.0032 & 0.07 & 2.57 \\
$0.5 \mathrm{MB}$ & 4.8 & -0.0015 & 0.34 & 2.52 \\
Dinorado & 4.8 & 0.0040 & 0.03 & 2.89 \\
$0.2 \mathrm{MB}$ & 4.3 & -0.0004 & 0.76 & 1.65 \\
RM & 4.2 & 0.0008 & 0.64 & 2.71 \\
$0.8 \mathrm{MB}$ & 2.6 & -0.0027 & 0.05 & 1.54 \\
MB & 2 & -0.0033 & 0.11 & 3.85 \\
\hline
\end{tabular}

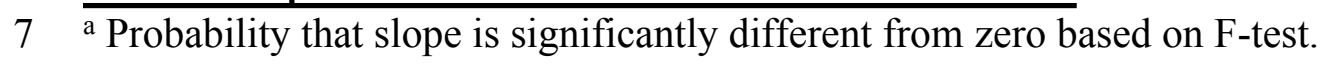

$8 \quad \mathrm{~b}$ Mean square error of the regression. 


\section{Figure 1}

Planting rice and mungbean in an experimental site in Mindanao with three-year-old rubber.

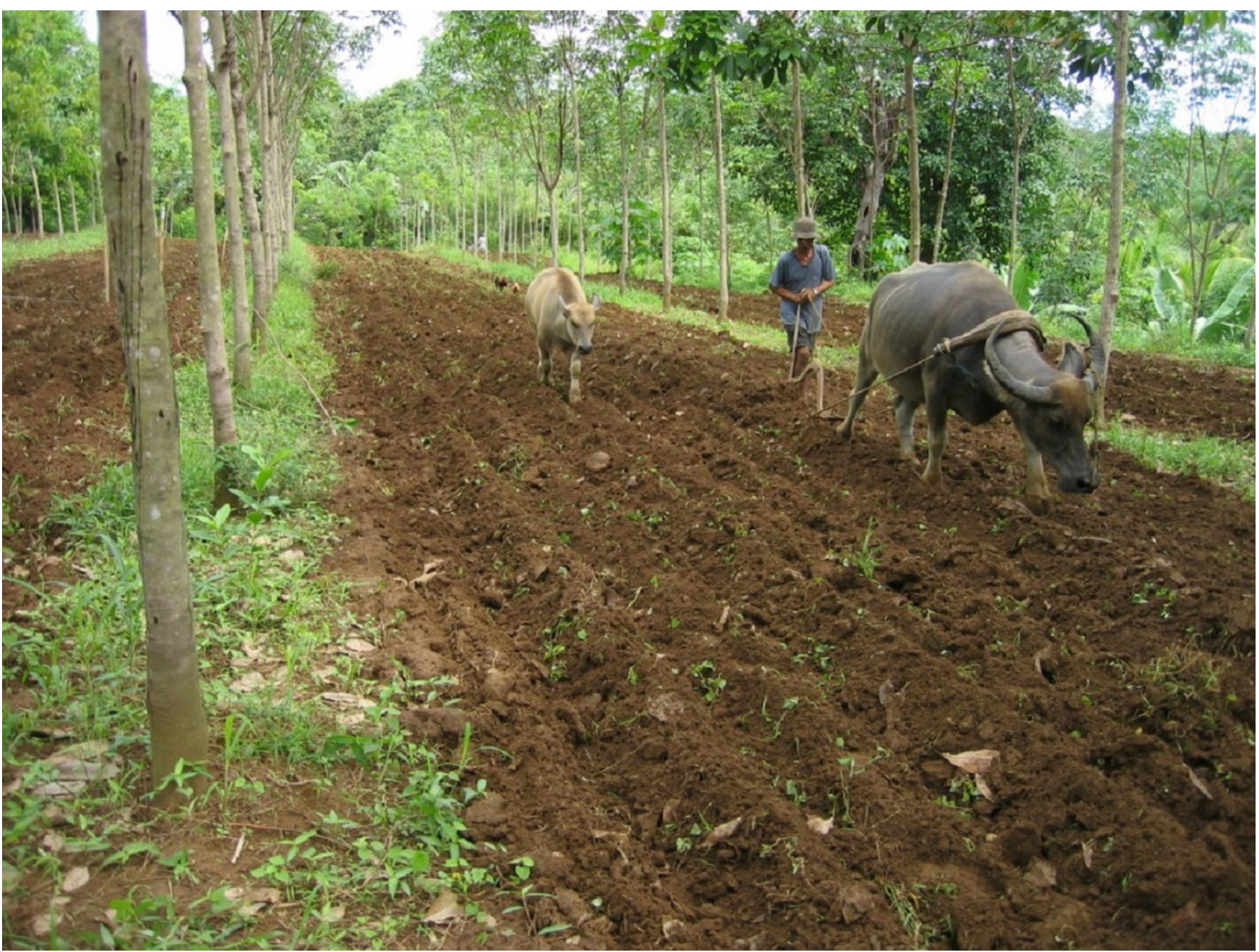


Figure 2 (on next page)

Yield ( $\mathrm{g} / \mathrm{row}$ ) of two rice cultivars (Dinorado and UPL Ri-5) and mungbean grown between rubber tree rows in a Mindanao plantation.

The rice and mungbean were grown in monoculture and in a set of mixture and intercropping treatments (Table 1). In the boxplots, the white bar indicates the median across all farms, the boundaries of the box indicate the $25^{\text {th }}$ and $75^{\text {th }}$ percentiles, the extent of the dotted lines indicate the minimum and maximum, and circles beyond these indicate more unusual values. 

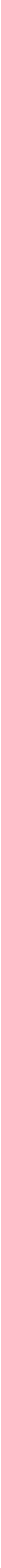

Mung Bean 。

800
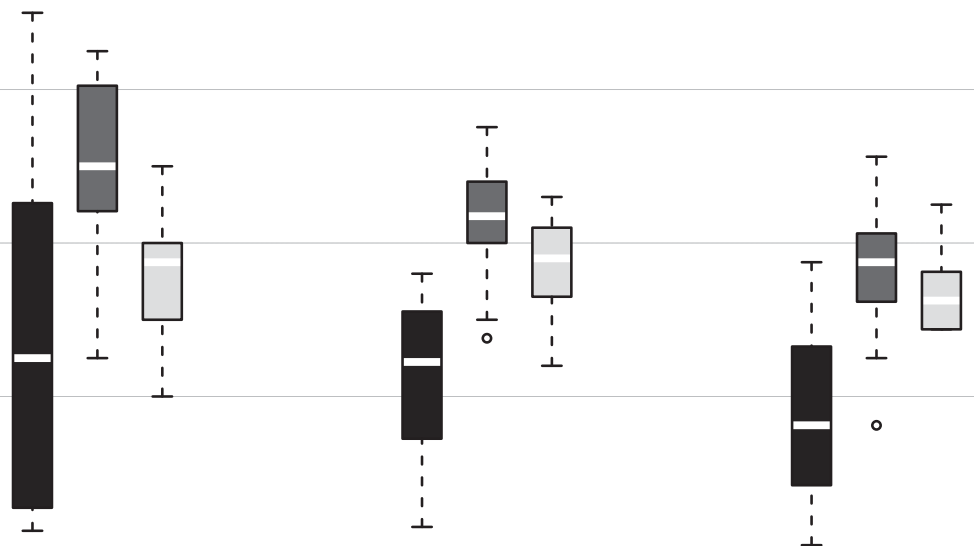

Peer) reviewing PDF | (2016:10:13648:1:1:NEW 4 Jan 2017) 
Figure 3 (on next page)

The Land Equivalent Ratio (LER) for a rice mixture and three intercropping systems (Table 1 ) in three years across all rubber plantations studied.

In the boxplots, the white bar indicates the median across all farms, the boundaries of the box indicate the $25^{\text {th }}$ and $75^{\text {th }}$ percentiles, the extent of the dotted lines indicate the minimum and maximum, and circles beyond these indicate more unusual values. These values were not weighted by the relative economic value of different crops. 


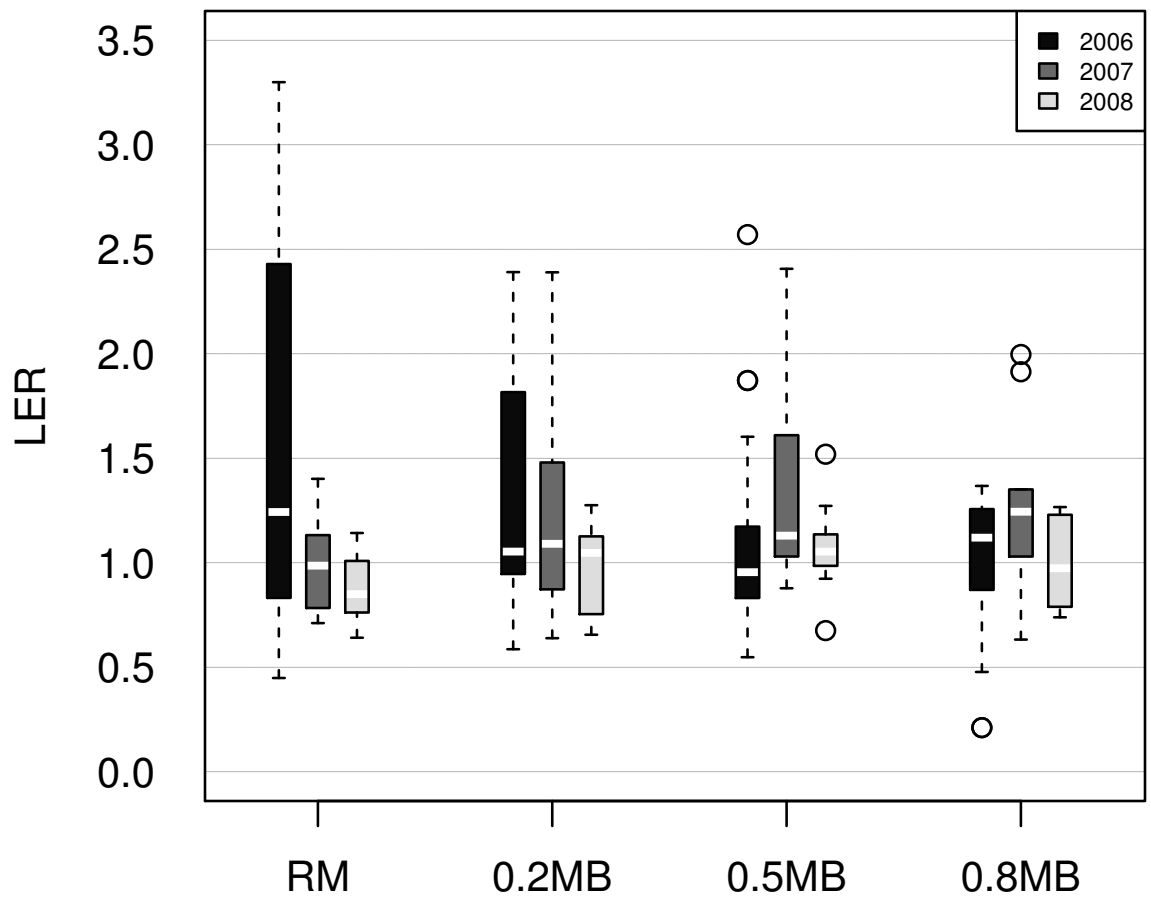

The mixtures 